\title{
Pathok Negoro: The Islamic Settlements in Modern Society
}

\author{
Desy Ayu Krisna Murti \\ Department of Architecture \\ Widya Maltaram University \\ Yogyakarta, Indonesia \\ desyayu@widyamataram.ac.id
}

\author{
Ahmad Sarwadi \\ Department of Architecture \\ Universitas Gadjah Mada \\ Yogyakarta, Indonesia \\ sarwadi@ugm.ac.id
}

\begin{abstract}
Pathok Negoro is a title for a person or a place that is the border of the region to Kasultanan Yogyakarta Hadiningrat after the division of the region based on the Giyanti Agreement. Originally Pathok Negoro established a mosque to accommodate the dawah institution to spread the development of Islam that formed by Sultan Hamengku Buwono I. Raden Sandeyo or Kyai Nur Iman is the man who served as the first Pathok Negoro on 1760, but at the time of the construction around the year 1723-1819. This research focused on how the existing Islamic settlements pattern in Pathok Negoro as the oldest Islamic Society in Yogyakarta.
\end{abstract}

Research locations in Mlangi and Plosokuning based on kinship with the sultan and the descendants of the nearest. Besides the tradition is still maintained in Mlangi and Plosokuning shows characteristics of Pathok Negoro. Mlangi has two levels of patterns concerning encircle the number of nodes in the form of mushola and Pondok pesantren as the many nuclei at the neighborhood level. The existence of two levels of the neighborhood in Mlangi done by Santri and Mlangi citizens. Plosokuning has a more dynamic nature in its development as a settlement, after the division of the area from the jobo and Jero Plosokuning then citizens there open up to the newcomers. If Mlangi has many boarding houses for Santri that have plenty of space to spread (multi nuclei/polycentric) then Plosokuning only has one area that became the center of activity as well as sacred sites that the form has the concentric shape of the distribution. All the nuclei as the center also formed by the natural condition as well, a Family kinship between the family of Kyai Nur Iman and Kyai Mursodo who being founders of Pathok Negoro Mlangi and Pathok Negoro Plosokuning.

Keywords: Pathok Negoro, Kasultanan, Islamic, society, Yogyakarta

\section{INTRODUCTION}

The term Pathok can be interpreted as a pillar that is intentionally placed in a certain place as a boundary sign that separates it from the area or region outside the pathok sign. However, the term pathok country known in the Sultanate of Yogyakarta independently means a sign that cannot change in an empire or country. Except that the above term is generally used to refer to mosques belonging to the Sultanate of Yogyakarta or in other languages called the kagungan dalem mosque (except the grand mosque). According to S.Ilmi Albiladiyah in his book Pathok Negari A Form of Law regulations in the 18th Century in Yogyakarta, published by the Institute for Traditional History and Values, 1993 stated that the term state pathok only applies to positions in a judicial institution. The name of the state Pathok which is then attached to the mosques of kagungan dalem is following a position prescribed, although the various table text styles are provided. The formatter will need to create these components, incorporating the applicable criteria that follow.

The Pathok Negoro were allowed to occupy a village and were built by a mosque. In further developments, the Pathok Negoro as well as leaders of mosque congregations in the village of Perdikan. The function of the Pathok Negoro Mosque beside the place of worship is as a place of study (reciting), majelis taklim (the Islamic study by group), a place of government, a court of justice, as well as a place of defense, in addition to places of death ceremonies, weddings, and other religious activities. Perdikan land is usually land contained in holy places such as the royal family's grave, sacred buildings (mosques) and religious scholars who are deemed meritorious. Pathok Negoro itself is mentioned as two things, namely:

a) The term Pathok Negoro is also used to refer to the mosque which is the responsibility of the official.

b) The term Pathok Negoro is also used to refer to the village where the Pathok Negoro mosque and the official inhabit it.

\section{ISSUES}

\section{A. General Issue}

Knowing how the function of the Pathok Negoro settlements that were formed became a settlement that could maintain tradition in the modern era.

\section{B. Specific Issue}

Mlangi and Plosokuning are the members of Pathok Negoro Constellation. The two of four Pathok also the most authentic till now. How they function in the reality of modern society still hold the tradition is the main idea of the concept from Pathok Negoro as Islamic Settlements. Now How they build this society into the shared space of around modern neighborhood the concern of the research.

\section{RESEARCH STRATEGY}

This research uses the observation with the qualitative method. Based on the objects that two locations in the separated distance. Because it's more appropriate if we use figure-ground to see the quality of space and density. And the direct observation of the locations of Mlangi and Plosokuning. According to the method, we look at the quality of their lives 


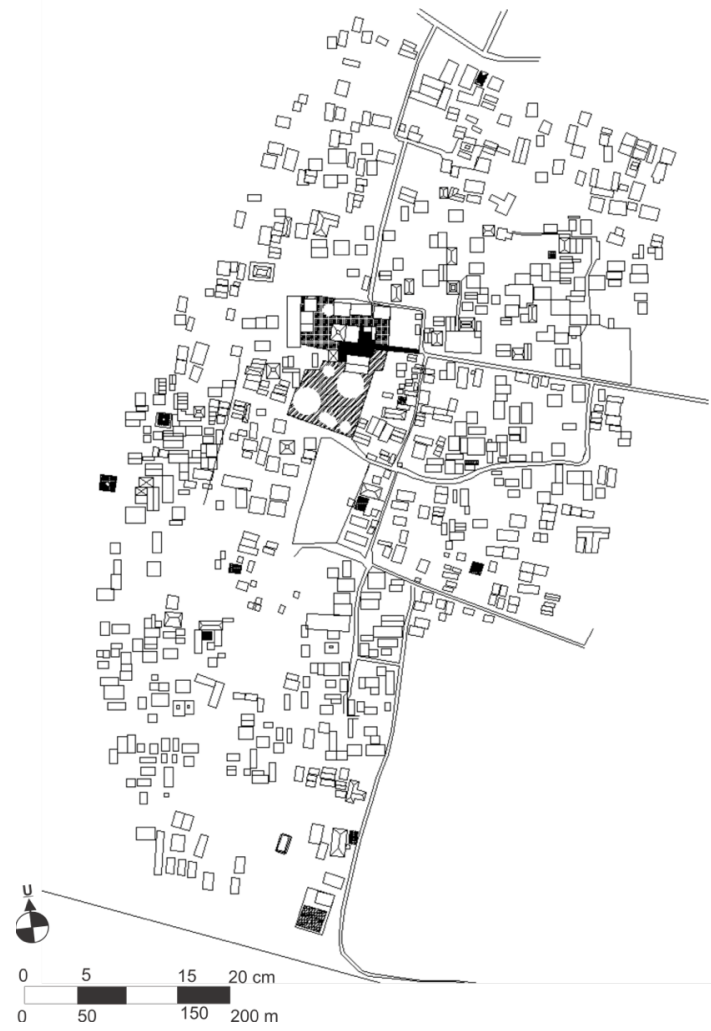

Fig. 2. Figure-ground of Mlangi settlements.

The relations between aspects according to Rapoport, Mlangi is relatable for the section. Economy, culture, social neighborhood and of course religion affiliationare connect each other.

The Pathok Negoro Mosque is the center of the settlements and Black dots which scattered around it are the mini mosque or they call it mushola. Mushola is a place for women to pray, read Quran, routine gathering and preparing the haul of Kyai Nur Iman every year. These activities always happen and then become a daily activity for them.

Mlangi as the first pathok negoro has the privilege to be the most popular Pathok Negoro in Yogyakarta. The people who live there are the descendant of Kyai Nur Iman. They married with neighborhood close to each other. They have belief in Islamic tradition to keep the legacy of mahzab kind of stream in faith based on syaria law. that is the reason why the tradition is still maintained today. Relations between relatives are very close.

The Mlangi predicate as a santri area exists, this is because Mlangi has 16 Islamic boarding schools which are the largest spread in Mlangi Look. Some Islamic religions in Mlangi receive NU and most of Muhammadiyah. They live with help having different views and procedures for worship. However, this does not reduce the religious value of Mlangi village. 

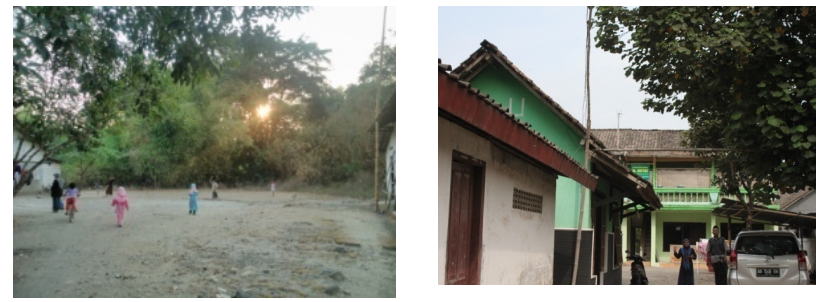

Fig. 3\&4. The environment around Mlangi and one of the mushola

\section{B. Ploso Kuning The North Border}

Plosokuning was founded after Mlangi, from a story told by local people that Plosokuning was founded by Kyai Nur Iman's son, Kyai Mursodo. In the book of the Historic Mosque of the Special Province of Yogyakarta, it is explained that the starting point of the Ploso Kuning mosque was built as a continuation of Sultan HB I's decision to order the cleric Nur Iman to build a mosque in Mlangi, then the cleric Nur Iman who had two sons, one of whom became a servant of the palace in Plosokuning. Raden Nawawi became a servant in Pathok Negoro in Mlangi while Raden Mursada was appointed as a servant in Pathok Negoro with the title of Kyai Hanafi I. The mosque was built during the era of Sultan HB III in 1812-1814. The name Plosokuning is taken from the name of the tree which is located 300 meters from the mosque's built point, yellow which means the color of the ploso tree leaves.

In general, the division of rooms in Plosokuning will not be seen if it does not come directly to the Sulthoni mosque then traces the history and deep areas of Padukuhan. Because of both the facade and the shape of the house now many have changed into modern buildings.

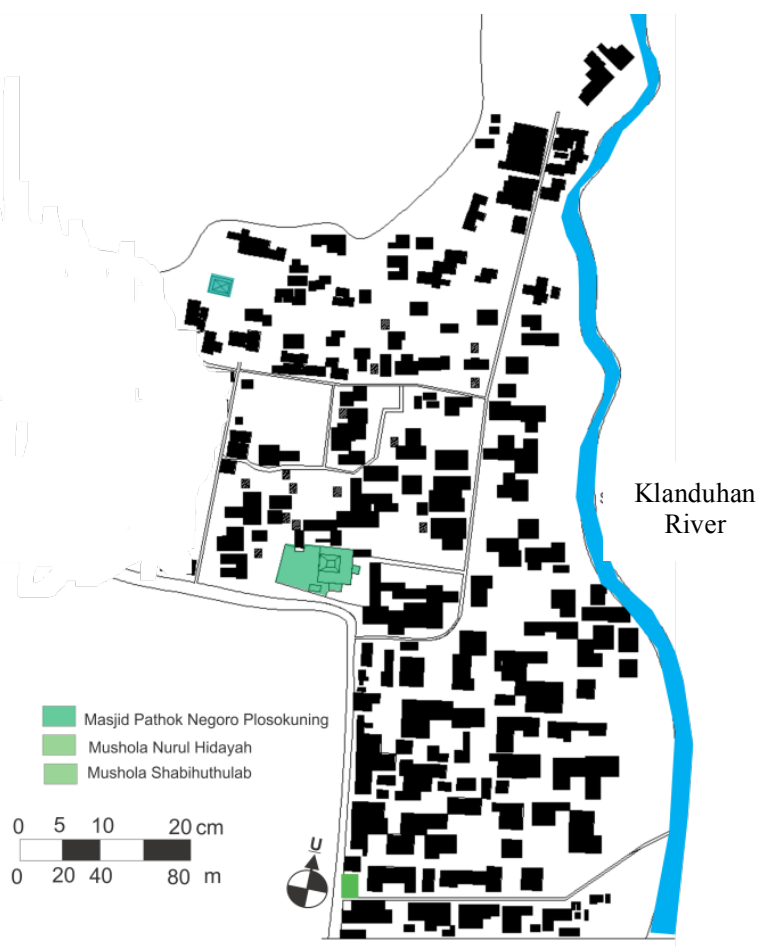

Kinship in Plosokuning makes a territorial determination like receiving in Mlangi. However, the difference in Plosokuning is where the administrators of Pathok Negoro who belong to Kyai Mursodo who still hold the title of Raden are called Plosokuning but are not related to the royal family and the founder of Pathok Negorod is called Plosokuning Jobo. Based on the informants who live in the Jero region located west of the mosque and the mosque's tomb. While Jobo lives outside it or is placed east of the mosque.

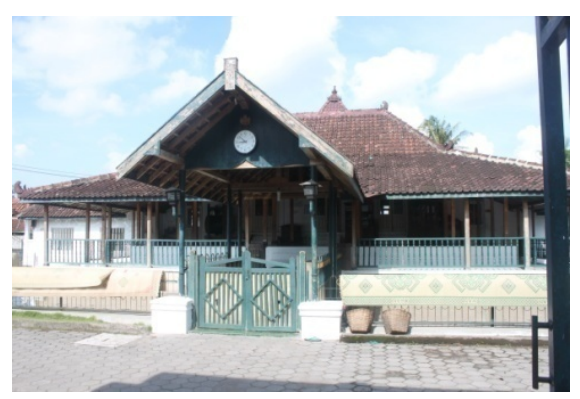

Fig 6. Mosque of Plosokuning.

The mosque as the center of all activities is the main forming. The roads in Plosokuning are now more grid-shaped. But some still have a small alleyway between houses, road consolidation. Both of kinship and religion, Plosokuning still has one node and one node at the center.

So that in Plosokuning IV it becomes a forum for various religious activities.

1. Plosokuning develops according to tradition.

2. Not many Islamic boarding schools exist that make the Plosokuning community more dynamic towards existing changes.

3. Patterns based on the kinship between Plosokuninng and Mlangi

Plosokuning has a more dynamic nature in its development as a settlement, after the division of areas from Plosokuning jobo and Jero, the residents there open themselves to migrants, this is evidenced by the emergence of new housing developments. The Pathok Negoro Mosque is the center of community activities there even though the community has moved modern now. So that the physical space is formed into several parts from Plosokuning I to Plosokuning VI but psychologically they still classify space based on wong jobo and wong jero.

Natural conditions that support making Plosokuning also develop the natural potential that exists in addition to farming Plosokuning residents from the past until now to cultivate freshwater fish. This is because the abundant water makes residents have a pool in each of their homes. 


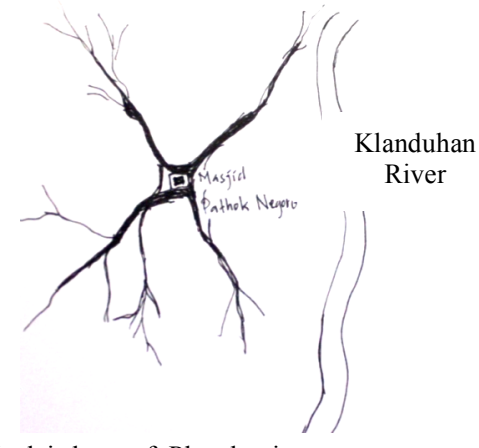

Fig. 7 Nuclei shape of Plosokuning.

\section{CONCLUSIONS}

The factors that influence these characteristics include:

$A$. from the time of the establishment of the Mosque Building to the present are: a. the religious aspects of the Yogyakarta Community, its influence is due to the religious system of the Yogyakarta Community which arises from the fusion of elements of the Islamic religion and culture of Yogyakarta. The religious system was then realized by a symbol system on the elements of the Pathok Negoro Mosque building.

B. Kinship system and social structure of the Yogyakarta Community, This element is in placing Kiai (ulama) in high social strata while in the Mosque. This has an impact on the design and alignment of Mihrab. The kinship system and social structure of the Yogyakarta community that adheres to the patrilineal system also influences the ratio of the main prayer room, the existence of pawestren, and the Hirarkhi room in the Pathok Negoro Mosque.

$C$. With the significant contour differences, Mlangi is divided into two. This division is quite strong in acquiring now that it has the administration of being Mangi and Sawahan but residents still have the perception that Mlangi is divided into two regions.

$D$. Of the four Pathok Negoro, two of them are Mlangi and Plosokuning. However, both of them have similarities and differences which, if seen from some of the elements that form the city as follows.
TABLE I. TABLE OF SETTLEMENTS FORMING FACTORS

\begin{tabular}{|c|c|}
\hline Mlangi & Plosokuning \\
\hline Nature & Nature \\
\hline Human relations & Human relations \\
\hline Social-Culture & Kinship \\
\hline Kinship & Psychology-Spiritual \\
\hline Psychology-Spiritual & \\
\hline
\end{tabular}

\section{ACKNOWLEDGMENT}

We would also like to show our gratitude to the Mlangi people, Plosokuning Takmir Official for sharing their precious wisdom with us during the course of this research, We are also immensely grateful to All Lecturers in Universitas Gadjah Mada who were the supervisors for their comments on research and also the previous lecturer in Islamic University of Indonesia (UII), Last but not least all partners in Architecture Program Widya Mataram University who always courage the author to do work and doing research. All although any errors are our own and should not tarnish the reputations of these esteemed persons.

\section{REFERENCES}

[1] A. Rapoport, Human Aspects of urban Form, Towards a manEnvironment Approach to Urban Form and Design. New York: Pergamon Press, 1977.

[2] L. V. Rijckevorsel, Dan R.D.S Hadiwidjaja, Babad Tanah Jawi. Den Haag: Waltevreden, 1925.

[3] C. Alexander, A Pattern Language, Towns. Building. Construction. New York : Oxford University press, 1977.

[4] Widyastuti, The Background Function of the Establishment and Role of Pathok Negoro Mosques in Yogyakarta (Fungsi Latar Belakang Pendirian Dan Peranan Masjid-Masjid Pathok Negoro Yogyakarta), Universitas Gadjah Mada. 1995. pg.45

[5] G. Fairclough, and friends, The Heritage Reader. New York: Routledge, 2008.

[6] D. A. K. Murti, Pola Permukiman Di Sekitar Masjid Pathok Negoro Mlangi Dan Plosokuning Yogyakarta. Thesis for Master Program Universitas Gadjah Mada. Yogyakarta, 2016. 